\title{
Cytokine profile in children with newly diagnosed tuberculosis
}

\author{
0. M. Raznatovska, Yu. V. Mironchuk
}

Zaporizhzhia State Medical University, Ukraine

Nowadays, the most important task of children's phthisiology is to increase the effectiveness of children with tuberculosis treatment, and in the first priority should be given to the first time diagnosed tuberculosis (FTDTB). Examination of the immune system state by cytokine profile in blood serum studying is paid to sufficient attention, as cytokines are the system which regulates the entire complex of organism protective reactions, and immunological dysregulation is the cause of pathological process increasing. There few data of the cytokine profile state studying in children with FTDTB in Ukraine in the available literature and various combinations of cytokines comprehensively with other immunological parameters are studied. According to our studies of the blood serum cytokine profile state in adult patients with tuberculosis, the reliable indices of immune system changes are interleukin (IL)-2, IL-6, IL-4 and IL-10.

The aim of the work is to study the indicators of blood serum cytokine profile (IL-2, IL-6, IL-4, IL-10) in children with FTDTB.

Materials and methods. The study of the cytokine profile indicators has been performed in 28 children with FTDTB, aged from 1 to 16 years old (an average age was $9.2 \pm 1.1$ years). The indicators of the cytokine profile were studied by researching the levels of IL-2, IL-6, IL-4, IL-10 in blood serum by ELISA technique on the equipment of Sirio S immuno-enzyme reader using "Bender MedSystems GmbH" (Austria) kit (pkg/ml). These indicators were evaluated at the beginning of antimycobacterial therapy intensive phase.

Results. Despite the fact that according to the data from BCG vaccination, $42.8 \%$ of children suffering from FTDTB had full immunity, the changes of cytokine profile indicators at the beginning of the disease were determined in $96.4 \%$ of cases. The peculiarities of cytokine profile changes in sick children were a significant decrease in the content of anti-inflammatory cytokine IL-4, increase in the content of proinflammatory cytokine IL-2 and decrease in the content of IL-6. With a decrease in immunity to tuberculosis infection created by BCG vaccine, a significant increase in IL-2 level in blood serum was determined.

Conclusions. The obtained data indicate that activation of Th1-type cell-mediated immune response (increase in IL-2 content and imbalance of cytokines with the prevalence of its production) is determined in children with FTDTB at the beginning of treatment, and the specific process does not have an active inflammatory reaction which is the cause of its progression (low content of IL-6). Therefore, in this category of children the factors of tuberculosis favorable course are determined at the beginning of treatment.

\section{Цитокіновий профікь у хворих Аітей на вперше діагностований туберкульоз}

\section{О. М. Разнатовська, Ю. В. Мирончук}

Сьогодні найважливішим завданням дитячої фтизіатрії є підвищення ефективності лікування дітей, які хворі на туберкульоз і передовсім - на вперше діагностований (ВДТБ). Дослідженню стану імунної системи шляхом вивчення цитокінового профілю в сироватці крові приділяється достатньо уваги, оскільки цитокіни є тією системою, що регулює весь комплекс захисних реакцій організму, а імунологічна дисрегуляція є причиною посилення патологічного процесу. Наявні в науковій літературі дані дослідження стану цитокінового профрілю у хворих дітей на ВДТБ в Україні нечисленні й вивчаються комплексно в різних поєднаннях цитокінів з іншими імунологічними показниками. За здійсненими нами дослідженнями стану цитокінового профілю в сироватці крові в дорослих хворих на туберкульоз вірогідними показниками змін імунної системи $є$ інтерлейкін (IL)-2, IL-6, IL-4 та IL-10.

Мета роботи - дослідити показники цитокінового профілю (IL-2, IL-6, IL-4, IL-10) у сироватці крові у хворих дітей на ВДТБ.

Матеріали та методи. Вивчення показників цитокінового профілю здійснили у 28 дітей, які хворі на ВДТБ, віком від 1 до 16 років (середній вік - 9,2 $\pm 1,1$ року). Показники цитокінового профрілю вивчали шляхом дослідження рівнів IL-2, IL-6, IL-4, IL-10 у сироватці крові методом твердофазного імуноферментного аналізу на приладі імуноферментний рідер Sirio $S$ iз застосуванням набору «Bender MedSystems $\mathrm{GmbH»} \mathrm{(Austria),} \mathrm{(пкг/мл).} \mathrm{Ці} \mathrm{показники} \mathrm{оцінювали} \mathrm{на} \mathrm{початку} \mathrm{інтенсивної} \mathrm{фрази}$ антимікобактеріальної терапії.

Результати. Незважаючи на те, що за даними щеплення вакциною БЦЖ 42,8 \% хворих дітей на ВДТБ мали повноцінний імунітет, на початку захворювання у 96,4 \% випадків визначаються вірогідні зміни показників цитокінового профілю. Особливостями змін цитокінового профрілю у хворих дітей є вірогідне зниження вмісту протизапального цитокіну IL-4, підвищення вмісту прозапального цитокіну IL-2 та зниження вмісту IL-6. При зниженні імунітету до туберкульозної інфекції, створеного вакциною БЦЖ, визначається вірогідне зростання рівня показника IL-2 в сироватці крові.

Висновки. Дані, що одержали, вказують: у хворих дітей на ВДТБ на початку лікування визначається активізація Тh1-типу імунної клітинної відповіді (підвищення вмісту IL-2 та дисбаланс цитокінів із переважанням його продукції), а специфічний процес не має активної запальної реакції, що є причиною його прогресування (низький вміст IL-6). Тому в цієї категорії дітей на початку лікування визначаються фактори сприятливого перебігу туберкульозу.

\section{Цитокиновый профиль у больных детей с впервые диагностированным туберкулёзом}

\section{Е. Н. Разнатовская, Ю. В. Мирончук}

На сегодня важнейшей задачей детской фртизиатрии является повышение эффективности лечения детей, больных туберкулёзом, и, в первую очередь, с впервые диагностированным (ВДТБ). Исследованию состояния иммунной системы путём изучения

Ключевые слова: цитокины, Аети, туберкулёз.
Key words: cytokines, children, tuberculosis.

\section{Zaporozhye} medical journal 2017; 19 (5), 601-603 Dol: 10.14739/2310-1210 2017.5.110162

E-mail: raxnatovskaya@ gmail.com

Ключові слова: цитокіни, Аіти, туберкульоз.

Запорізький медичний журнал. - 2017. T. 19, № 5(104). C. $601-603$ 
Запорожский медицинский журнал. - 2017. -

T. 19, № 5(104). C. $601-603$

цитокинового профиля в сыворотке крови уделяется достаточно внимания, поскольку цитокины являются той системой, которая регулирует весь комплекс защитных реакций организма, а иммунологическая дисрегуляция является причиной усиления патологического процесса. Имеющиеся в научной литературе данные исследования состояния цитокинового профиля у больных детей с ВДТБ в Украине немногочисленны и изучаются комплексно в различных сочетаниях цитокинов с другими иммунологическими показателями. По проведённым нами исследованиям состояния цитокинового профиля в сыворотке крови у взрослых, больных туберкулёзом, достоверными показателями изменений иммунной системы является интерлейкин (IL)-2, IL-6, IL-4 и IL-10.

Цель работы - исследовать показатели цитокинового профиля (IL-2, IL-6, IL-4, IL-10) в сыворотке крови у больных детей с ВДТБ.

Материалы и методы. Изучение показателей цитокинового профиля проведено у 28 детей, больных ВДТБ, в возрасте от 1 до 16 лет (средний возраст - 9,2 \pm 1,1 года). Показатели цитокинового просриля изучали путём исследования уровней IL-2, IL-6, IL-4, IL-10 в сыворотке крови методом твердофазного иммуноферментного анализа на приборе иммуноферментный ридер Sirio S с применением набора «Bender MedSystems GmbH» (Austria), (пг/мл). Эти показатели оценивали в начале интенсивной фазы антимикобактериальной терапии.

Результаты. Несмотря на то, что по данным прививки вакциной БЦЖ 42,8 \% больных детей с ВДТБ имели полноценный иммунитет, в начале заболевания в 96,4 \% случаев определяются достоверные изменения показателей цитокинового профиля. Особенностями изменений цитокинового профиля у больных детей является достоверное снижение содержания противовоспалительного цитокина IL-4, повышение содержания провоспалительных цитокинов IL-2 и снижение содержания IL-6. При снижении иммунитета к туберкулёзной инсеекции, созданного вакциной БЦЖ, определяется достоверное повышение уровня показателя IL-2 в сыворотке крови.

Выводы. Полученные данные указывают на то, что у больных детей с ВДТБ в начале лечения определяется активизация Th1-типа иммунного клеточного ответа (повышение содержания IL-2 и дисбаланс цитокинов с преобладанием его продукции), а специсический процесс не имеет активной воспалительной реакции, которая является причиной его прогрессирования (низкое содержание IL-6). Поэтому в этой категории детей в начале лечения определяются факторы благоприятного течения туберкулёза.

Nowadays, the most important task of children's phthisiology is to increase the effectiveness of children with tuberculosis treatment, and in the first priority should be given to the first time diagnosed tuberculosis (FTDTB) [1]. Examination of the immune system state by cytokine profile in blood serum studying is paid to sufficient attention, as cytokines are the system which regulates the entire complex of organism protective reactions, and immunological dysregulation is the cause of pathological process increasing [2,3].

There few data of the cytokine profile state studying in children with FTDTB in Ukraine in the available literature and various combinations of cytokines comprehensively with other immunological parameters are studied $[4,5]$ According to our studies of the blood serum cytokine profile state in adult patients with tuberculosis, the reliable indices of immune system changes are interleukin (IL) -2, IL-6, IL-4 and IL-10 [6].

\section{The aim of the work}

The aim of the work is to study the indicators of blood serum cytokine profile (IL-2, IL-6, IL-4, IL-10) in children with FTDTB.

\section{Materials and methods}

The study of the cytokine profile indicators has been performed in 28 children with FTDTB, aged from 1 to 16 years old (an average age was $9.2 \pm 1.1$ years) who have been in inpatient care at the Children's Department of the Phthisiology and Pulmonology Department Clinical Base of ZSMU, Communal Institution "Zaporizhzhia Regional Antituberculosis Clinic Dispensary" (the main group). 16 (57.1\%) were girls, $12(42.9 \%)$ were boys. The comparison group included 30 healthy children vaccinated with BCG vaccine, not infected with mycobacterium tuberculosis (Koch's bacillus). Comparative groups have been comparable to age and gender.

The indicators of the cytokine profile were studied by researching the levels of IL-2, IL-6, IL-4, IL-10 in blood serum by ELISA technique on the equipment of Sirio $S$ immuno-enzyme reader using "Bender MedSystems GmbH" (Austria) $\mathrm{kit}(\mathrm{pkg} / \mathrm{ml})$. These indicators were evaluated at the beginning of antimycobacterial therapy (AMBT) intensive phase. The parents of all sick children signed an informed written consent of the patient to participate in the study.

The results of the study were processed by modern methods of analysis on a personal computer using Statistica ${ }^{\circledR}$ for Windows 6.0 statistical software package (StatSoft Inc., AXXR712 D833214FAN5). The normality of quantitative characteristics distribution was analyzed using the Shapiro-Wildlife test. The descriptive statistics for quantitative variables distributed under the normal distribution law included the mean (M), the standard deviation $(\sigma)$. A confidence interval for the average one with a confidence probability of 0.95 was constructed. The reliability of the differences in the comparable values was determined by the Student's t-test. All tests were double. The difference for $p<0.05$ considered statistically significant. Correlation analysis was performed using the Pearson correlation coefficient ( $r$ )

\section{Results and discussion}

At the time of the survey, the positive reactions to Mantoux test with 2 tuberculin units (TU) and to the tubercular recombinant allergen test (TRA) in all children of the main group were determined. Therefore, tuberculin sensitivity was assessed as an infectious allergy. The TRA test response was negative in all children of comparison group.

In the main observed group antituberculosis vaccination BCG was performed on 23 children (82.1\%), and 5 children $(17.9 \%)$ were not vaccinated. Among the children vaccinated with BCG vaccine, one child (3.6\%) did not have a postvaccinal mark indicating the absence of postvaccinal immunity. Immunity reduction to tuberculosis infection created by $B C G$ was assessed based on weak intensity of local reaction to vaccination: the size of the postvaccinal mark was up 
to $5 \mathrm{~mm}$. Such a response to the BCG vaccination was in 10 children with FTDTB (35.7 \%), and 12 children (42.8\%) had a complete postvaccinal response.

Thus, taking into account the BCG vaccination data, only $42.8 \%$ of children suffering from FTDTB had full immunity to tuberculosis infection, $35.7 \%$ were weak and $21.5 \%$ had a lack of it at the time of suffering from tuberculosis.

At the beginning of AMBT intensive phase the indicators of cytokine in blood serum were within the normal range only in one child (3.6\%), while the rest of the children with FTDTB had reliable changes of IL-6, IL-4 and IL-2 indices (Table 1).

According to the obtained data in children suffering from FTDTB against a background of a significant decrease in the content of anti-inflammatory cytokine IL-4 by 3 times $(0.56 \pm 0.04$ against $1.72 \pm 0.05) \mathrm{pkg} / \mathrm{ml}$ and normal content of IL-10, a significant increase in the content of proinflammatory cytokine IL-2 by 6.3 times $(2.73 \pm 1.1$ against $0.43 \pm 0.09$ ) $\mathrm{pkg} / \mathrm{ml}$ was determined, indicating the Th1-type of immune cell-mediated response activation. A significant reduction in the content of IL- 6 in 2.4 times $(0.64 \pm 0.3$ against $1.59 \pm 0.04) \mathrm{pkg} / \mathrm{ml}$ demonstrated that specific process had no active inflammatory reaction in children with FTDTB, that was the cause of its progression.

The balanced state of pro- and anti-inflammatory cytokines ratio gave in indication of IL-2/IL-10 index calculation not significantly, which was in children with FTDTB, compared with healthy persons, but 7 times higher $(2.57 \pm 1.2$ against $0.14 \pm 0.03$ ) indicated the imbalance of cytokines with prevalence of pro-inflammatory cytokine production - IL-2, which confirmed the activation of the Th1-type cell-mediated response.

At the same time, a reliable correlation between the IL-2 blood serum level increase and the local reaction to BCG vaccination intensity $(r=0.402 ; p<0.05)$ in the children of the main group has been found. With other indicators of the cytokine profile any reliable correlations with the local reactions to $B C G$ vaccination intensity has not been found.

\section{Conclusions}

1. Despite the fact that according to the data on BCG vaccination $42.8 \%$ of children suffering from FTDTB had full immunity the changes of cytokine profile indicators were determined in $96.4 \%$ of cases at the beginning of disease.

2. The peculiarities of cytokine profile changes in sick children are a significant decrease in the content of anti-inflammatory cytokine IL-4, increase in the content of proinflammatory cytokine IL-2 and decrease in the content of IL-6.

3. With a decrease in immunity to tuberculosis infection created by BCG vaccine, a significant increase in the level of IL-2 in blood serum is determined.

3. The obtained data indicate that activation of Th1-type immune cell-mediated response (increase in the content of IL-2 and imbalance of cytokines with the prevalence of its production) is determined in the children with FTDTB at the beginning of treatment, and specific process does not have an active inflammatory reaction which is the cause of its progression (low content of IL-6). Therefore, in this category of children the factors of tuberculosis favorable course are determined at the beginning of treatment.

Prospects for further researches. Study further the immune system state in children with FTDTB in the process of AMBT in order to develop a pathogenetic correction of re-
Table 1. Content of cytokines in blood serum in children with FTDTB at the beginning of the intensive phase of $\mathrm{AMBT}(\mathrm{M} \pm \mathrm{m})$

\begin{tabular}{llllll}
\hline \multirow{2}{*}{ Group } & $\begin{array}{l}\text { Number } \\
\text { of sick patients }\end{array}$ & \multicolumn{4}{l}{ Levels of cytokines in the blood serum, pkg/ml } \\
\cline { 3 - 6 } & IL-6 & IL-4 & IL-2 & IL-10 \\
\hline Comparison Group & 30 & $1.59 \pm 0.04$ & $1.72 \pm 0.05$ & $0.43 \pm 0.09$ & $3.31 \pm 0.09$ \\
Main Group & 28 & $0.64 \pm 0.3^{*}$ & $0.56 \pm 0.04^{*}$ & $2.73 \pm 1.1^{*}$ & $3.20 \pm 0.8$ \\
\hline
\end{tabular}

*: the difference in the content of one cytokine compared with the indicator of healthy children group $(p<0.05)$.

vealed violations, which would contribute to improvement of this sick children category treatment.

\section{References}

[1] Belogortseva, O. I. (2014). Epidemiolohichna sytuatsiia shchodo tuberkulozu u ditei v Ukraini ta shliakhy udoskonalennia nadannia protytuberkuloznoi dopomohy ditiam [The epidemiological situation of tuberculosis in children in Ukraine and ways to improve TB care to children]. Sovremennaya pediatriya, 5, 22-26. [in Ukrainian].

[2] Vivchar, I. S., \& Zaletskiy, N. P. (2014). Korrelyacionnye svyazi pokazatelej immunnogo i citokinovogo statusa u detej i podrostkov, bol'nykh tuberkulezom legkikh [Correlation of indicators immune and cytokine status in children and adolescents with pulmonary tuberculosis]. Nauchnoe obozrenie. Medicinskie nauki, 1, 122-123. [in Russian].

[3] Shlyahova, N. V., \& Plekhova, O. I. (2014). Izmeneniya citokinovogo profilya u zdorovykh detej i podrostkov na etapakh polovogo sozrevaniya [Cytokine profile changes in healthy children and adolescents in the puberty stages]. Ukrainskyi zhurnal dytiachoi endokrynolohi, 1, 7-14. [in Ukrainian].

[4] Bilogortseva, O. I., Pobedonna, G. P., Rekalova, O. M., Dotsenko, Ya. I., Koposova, I. V., \& Firsova, A. P. (2015). Osoblyvosti stanu imunitetu u ditei, khvorykh na vpershe diahnostovanyi tuberkuloz [Peculiarities of immune status in children with newly diagnosed tuberculosis]. Ukrainskyi pulmonolohichnyi zhurnal, 3, 20-24. [in Ukrainian].

[5] Piskur, Z. I., Mykolyshyn, L. I., Platonova, I. L., \& Lapovets, L. Ye. (2017) Osoblyvosti tsytokinovoho spektra IL-1 $\beta$, IL-2, IL-10 i TNF- $\alpha$ u ditei, khvorykh na tuberkuloz [Features range of cytokine IL-1 $\beta$, IL-2, IL-10 and TNF- $\alpha$ in children with tuberculosis]. Tuberkuloz, lehenevi khvoroby, VIL-infektsiia, 1, 42-47. [in Ukrainian].

[6] Raznatovskaja, E. N. (2013). Immunologicheskiye osobennosti khimiorezistentnogo tuberkuleza legkikh [Immunological features of chemoresistant pulmonary tuberculosis]. Saarbrucken, Deutschland: LAP LAMBERT Academic Publishing. [in Ukrainian].

\section{Відомості про авторів:}

Разнатовська О. М., А-р меА. наук, Аоцент, професор каф. фтизіатрії та пульмонології, Запорізький державний медичний університет, Україна.

Мирончук Ю. В., викладач-стажист каф. фтизіатрії та пульмонології, Запорізький державний медичний університет, Україна.

\section{Сведения об авторах:}

Разнатовская Е. Н., А-р меА. наук, Аоцент, профессор каф. фтизиатрии и пульмонологии, Запорожский государственный медицинский университет, Украина. Мирончук Ю. В., преподаватель-стажёр каф. фтизиатрии и пульмонологии, Запорожский государственный медицинский университет, Украина.

\section{Information about author:}

Raznatovska O. M., MD, PhD, DSci, Associate Professor, Professor, Department of Phthisiology and Pulmonology, Zaporizhzhia State Medical University, Ukraine.

Mironchuk Yu. V., MD, Teacher Trainee, Department of Phthisiology and Pulmonology, Zaporizhzhia State Medical University, Ukraine.

Конфлікт інтересів: віАсутній.

Conflicts of Interest: authors have no conflict of interest to declare.

Надійшло Ао редакції / Received: 22.06.2017

Після Аоопрацювання / Revised: 26.06.2017

Прийнято Ао Аруку / Accepted: 07.07.2017 